\title{
Risk and risk management strategies of smallholder onion farmers in Sokoto state, Nigeria
}

\author{
Tohib Oyeyode OBALOLA ${ }^{1 *}$ and Opeyemi Eyitayo AYINDE ${ }^{2}$
}

Received November 23, 2017; accepted October 08, 2018.

Delo je prispelo 23. novembra 2017, sprejeto 08. oktobra 2018.

\begin{abstract}
The study examines risk and its management strategies among smallholder onion farmers in Sokoto State. Data were collected with the use of structured questionnaire designed to pull together information on the socioeconomic characteristics of the farmers in the area such as age, level of education, experience, family size, membership of farmer association, extension contact, risk preference of the farmers etc. Data was also collected on risk sources and risk management strategies. The primary data used were obtained from structured questionnaire administered to 120 randomly selected farmers. The analytical techniques that were used in the analysis of data were descriptive statistical tools such as means and percentages, Equally Likely Certainty Equivalent with a Purely Hypothetical Risky prospect (ELCEPH) technique and the 5-point Likert scale. The result showed that majority of the farmers are risk averse having a positive Arrow-Pratt absolute risk aversion coefficient.
\end{abstract}

Key words: risk; risk management; onion; smallholder farmers; strategies; ELCEPH
IZVLEČEK

\author{
TVEGANJA IN STRATEGIJE UPRAVLJANJA S \\ TVEGANJI MAJHNIH PRIDELOVALCEV ČEBULE V \\ DRŽAVI SOKOTO, NIGERIJA
}

Raziskava preučuje tveganja in strategije upravljanja $\mathrm{s}$ tveganji majhnih pridelovalcev čebule $\mathrm{v}$ državi Sokoto, $\mathrm{v}$ Nigeriji. Podatki so bili zbrani z vprašalnikom, ki je bil zasnovan tako, da je zbral podatke o socioekonomskih lastnostih kmetov na območju kot so starost, raven izobrazbe, izkušenost, velikost družin, članstvo v kmečkih združenjih, povezava s svetovalno službo, prednostna tveganja kmetov, itd. Podatki so bili izbrani tudi glede na vire tveganja in strategije upravljanja $\mathrm{z}$ njimi. Primarni podatki so bili pridobljeni z vprašalnikom, ki ga je izpolnilo 120 naključno izbranih kmetov. Pri obdelavi podatkov so bila uporabljena orodja opisne statistike kot so poprečja in odstotki. Uporabljena sta bila ekvivalent enako verjetne gotovosti in tehnika popolnega hipotetičnega predvidevanja tveganja (ELCEPH) in pettočkovna Likertova skala. Rezultati so pokazali, da se večina kmetov izogiba tveganju, saj imajo pozitiven Arrow-Prattov koeficient absolutnega odklanjanja tveganj.

Ključne besede: tveganje; upravljanje s tveganji; čebula; majhni pridelovalci; strategije; ELCEPH

\section{INTRODUCTION}

Agricultural production is highly characterized by risks, which range from adverse weather, pests to diseases, which in turn lead to price uncertainty (Ayinde et al., 2008). For these reasons, farmers' attitude towards risk is imperative in understanding their behavior towards the adoption of new technology and managerial decisions. For example, the more risk-averse a farmer is, the more likely the farmer is to make managerial decisions that emphasize the goal of reducing variation in income, rather than the goal of maximizing income; the converse is also true (Binici et al., 2003).

Production, which is considered as risky investment activity, takes place under either a perfect or an imperfect knowledge situation. A perfect knowledge occurs when the cause (action) and results are known

1 Department of Agricultural Economics, Usmanu Danfodiyo University, P.M.B. 2346, Sokoto, Nigeria; *Corresponding author: oyeyodeobalola@yahoo.com

2 Department of Agricultural Economics and Farm Management, University of Ilorin, P.M.B. 1515, Ilorin, Kwara State, Nigeria 
with certainty. Most economic analyses assume a perfect knowledge which is more theoretical than real. An imperfect knowledge situation occurs when the decision-maker (farmer) is not very sure of the result(s) of the action to be undertaken. A situation of imperfect knowledge is more common in agricultural enterprises than non-agricultural enterprises. However, there are two variants of imperfect knowledge situations. One of them is a situation of uncertainty, in which either all the possible outcomes of an event/action or the probabilities associated with each outcome or both are not known. The other is a situation of risk, which occurs when all possible outcomes for a given management decision (action) and the probability associated with each possible outcome are known (Kay, 1981).

In Nigeria, onion is produced through commercial as well as smallholder farmers both as a source of income and food. However, due to perishable nature and biological nature of production process, onion productions are risky investment activities. The behavior of farmers under risk has been studied using two approaches. The expected utility model (EUM) which is an extension of the consumer behavior theory in which consumer behave like they have a utility function and make choices that maximize it. The second approach, been a situation in which risk is defined as the likelihood that income will fall below a predetermined disaster level thus, giving rise to the safety first models
(SFM). Riskiness of onion production may be atributed to several factors that are beyond the control of the farmers. Sokoto state is endowed with resources for onion production but smallholder onion farmers in the state are faced with many risks in their farming activities. In the past, the state has recorded flood, drought, crop and animal diseases and pests as well as fluctuations in prices of both farm produce (outputs) and inputs. As a result, there has been variability in farmer's household income. The lack of clear understanding of farmers' attitudes towards risks remains an important factor inhibiting increased agricultural productivity. It is not in any way difficult to find out that the observed resource use of the farmers reveals their underlying degrees of risk preferences (Olarinde et al., 2008).

Researches on risk analysis in Sokoto State of Nigeria are relatively scanty. However, there is no real evidence to prove the expectations of the behavior of farmers in the production environment. There is a need to have a better understanding of the risk and the coping strategies among onion farmers in order to ascertain the decisionmaking behaviors of the farmers, to develop appropriate risk-coping strategies for the farmers, and to add to the existing knowledge in the field of agricultural risk in the study area. These are key issues central to this study and which investigation can be useful for the formulation of policies to strengthen and improve the farmers' productivity.

\section{MATERIAL AND METHODS}

\subsection{Study area}

Sokoto state is situated in the north-western part of Nigeria, close to Sokoto and Rima rivers confluence. It is situated between Latitudes $10^{\circ} 40^{\prime}$ and $13^{\circ} 55^{\prime} \mathrm{N}$ and longitudes $3^{\circ} 30^{\prime}$ and $7^{\circ} 06^{\prime} \mathrm{E}$ (Singh, 2000). It is one of the hottest region in the world. The maximum daytime temperature generally is under $40{ }^{\circ} \mathrm{C}\left(104.0^{0} \mathrm{~F}\right)$. The state falls within the semi-arid region where rainfall range from (400 - $700 \mathrm{~mm}$ per annum) which is erratic and poorly distributed (Singh, 1995). The main source of livelihood of the dwellers is farming and the crops cultivated include both food and cash crops such as millet, sorghum, rice, groundnut, cotton, cowpea, cassava and sweet potatoes. In addition, vegetable crops like onion, tomato, as well as sweet and hot peppers are grown during dry season under irrigation.

\subsection{Sampling procedure}

A multi-stage sampling technique was used to select 120 farmers. In the first stage, two local government areas were purposively selected. The reason for the purposive selection was on the preponderance of smallscale onion farmers in these LGAs. The second stage involved a random selection of two villages from each LGA. In the third stage, there was a random selection of respondents each from the LGA and this form the sample size for the study. Since the population of the LGAs is not homogeneous, the number of farmers selected from each of the selected LGAs was calculated using the formula:

$\mathrm{P}=\frac{S}{N} \times \mathrm{n}$

Where, $\mathrm{P}=$ Proportion, $\mathrm{S}=$ Desired sample size, $\mathrm{N}=$ Total population, $\mathrm{n}=$ Population of the villages in LGA in question. The LGAs and the number of respondents are shown in Table 1 below. 
Table 1: The local government areas and the number of farmers.

\begin{tabular}{cll}
\hline Local Government Area & Village & Sample \\
\hline Wamakko & Kwalkwalawa & 23 \\
& Kalambaina & 26 \\
Kware & RuggarLiman & 40 \\
& More & 31 \\
\hline Total & & 120 \\
\hline
\end{tabular}

Source: Authors computation

\subsection{Analytical technique}

Descriptive statistical tools such as means, percentages etc., Equally Likely Certainty Equavilent with a Purely Hypothetical technique and the 5-point Likert scale type were used.

\subsubsection{ELCE-PH}

This process begins by assigning the expected utility (EU) at two end point outcomes. Considering a low income of N 50, 000 and a high income of N 100, 000. This was followed by assigning utility value at each end point (low and high income) such that:

$\mathrm{U}(50,000)=0$

$\mathrm{U}(100,000)=1$, respectively for the low and high income end point outcome.

The researcher then asked the farmers how much they would be willing to take i.e. its certainty equivalent (CE) for a gamble paying of N50, 000 and N100, 000 with equal probability of 0.5 each. The CE was then used for utility function elicitation. The figures resulting from the elicitation sequence was then fit using the quadratic utility specification to yield:
$\mathrm{U}(\mathrm{Y})=\mathrm{a}+\mathrm{bY}+\mathrm{c \textrm {Y } ^ { 2 }}$

Where $\mathrm{Y}$ represents the unknown, and $\mathrm{a}, \mathrm{b}$, and $\mathrm{c}$ represent known numbers such that: 'c' is not equal to 0 . If $\mathrm{c}=0$, then the equation is linear and not quadratic.

The coefficients gotten from the fitted equation were used to estimate absolute risk-aversion coefficient. The coefficient was computed using equation below.

$r_{a}=-\frac{U^{\prime \prime}(Y)}{U^{\prime}(Y)}$

Where $r_{a}=$ coefficient of absolute risk aversion;

U' = second differential of the function;

$U^{\prime}=$ first differential of the function

The Arrow-pratt coefficient is positive if the individual is averse to risk, zero in the case of an individual that is indifferent to risk, and negative if the individual prefers to take risk (Korir, 2011).

\section{RESULTS AND DISCUSSION}

\subsection{Socioeconomic characteristics of the farmers}

The results (Table 2) show that $21.7 \%$ of the farmers are within the age group of $20-29$ years, while $26.7 \%$ of them fall within the age group $30-39$ years old. $40.8 \%$ and $10.8 \%$ are observed for the $40-49$ and 50 years above, respectively. The indication is that, most of the farmers are still very young, agriculturally active and energetic and the implication is their likeliness to have prospects for improvement upon their efficiency in onion production by better harnessing available production resources. Majority of the onion farmers $(64.2 \%)$ are married. The unmarried farmers constitute the minority $(35.8 \%)$. The implication of this is that those with children are assumed to have cheap agricultural family labour which will aid in the timely accomplishment of farm operations and in turn increases output at reduced rate.
Education provides a base of understanding changes within agriculture, which may improve welfare and as such education is essential in any activity. The level of education determines the quality of skills of farmer, his allocative abilities and shows how informed they are of the new innovations and technology around him. In Table 2, majority of the farmer $(63.3 \%)$ had no formal education. Farmers with completed primary education constitute $17.5 \%$. Secondary education is achieved by $19.2 \%$ of the farmers. The outcome is not a surprising one as the area falls within educationally deprived state of Nigeria. It corroborate with the finding of Tsoho and Salau (2012). Experience in farming is an essential factor affecting the farmer's level of production. Experienced farmers are able to combine factors of production (land, labour and capital) better to maximize output. However, $41.7 \%$ of the farmers sampled have been into onion farming for between $1-10$ years. Also, $42.5 \%$ and $15.8 \%$ of the farmers were within $11-20$ 
and 21-30 years respectively. The experience years will significantly increase the farmers' attitude towards decision making.

A household usually comprise of the man, his wife, children and other dependents if any. Majority of farmers $(50.0 \%)$ have 3-10 persons in the household. Another reasonable percentage $(42.5 \%)$ had 18 and above household member. All the above representations may be found important as it reduces the costs of production likely to be incurred by farmers with fewer household members. The polygamous nature as well as the family pattern of the area probably will explain the large family size recorded in the area. It is against the findings of Okoruwa, et al. (2009) which showed that $64.4 \%$ of the farmers had less than 6 family members while $35.6 \%$ had 6 and above. Also majority of the farmers $(68.3 \%)$ have no extension visit in the last cropping season. However, it was revealed that $21.7 \%$ of the farmers have an extension visit of between $1-2$ times, with $10.0 \%$ between $3-4$ times in the last growing season. It corroborates with the finding of Ojo et al. (2009) who reported that $60.9 \%$ of the farmers do not have extension contact.
Table 2 also shows the responses of the onion farmers as regards to their level of income obtained from onion production. It was observed that $40.0 \%$ of the farmers are of income level between N51, $000.00-\mathrm{N} 150$, 000.00. Another $35.0 \%$ indicates farmers that fall between N 151,000 - N 250,000.

The size of the farm is concerned with the land size. Land is a very important factor of production alongside with labour, capital and management. It is a true statement to say that without land, there is no agriculture. The size of the farm is vital to a farmer and the production of output. In view of this importance, questions are set about their farm sizes, since the size of the farm to some degrees determine the input to be used and responses shows that $54.2 \%$ farmers have farm sizes between $0.7-1.1$ hectare. Only a few of them have about 1.7 hectare and above. However, conclusion can be inferred that the farmers are smallholder onion farmers that limit their production on small hectares of land due to one reason or the other. It is in contrary to the work of Tsoho and Salau (2012), whose analysis although revealed that farm size ranged from 0.13 to 1.7 ha with the mean of 0.5 ha.

Table 2: Socioeconomic characteristics of the farmers

\begin{tabular}{llll}
\hline Parameter & Option & Frequency & Percentage \\
\hline Age (years) & $20-29$ & 26 & 21.7 \\
& $30-39$ & 32 & 26.7 \\
& $40-49$ & 49 & 40.8 \\
& 50 and ABOVE & 13 & 10.8 \\
\hline Marital status & Single & 43 & 35.8 \\
& Married & 77 & 64.2 \\
\hline Level of education (years) & No formal education & 76 & 63.3 \\
& Primary education & 21 & 17.5 \\
& Secondary education & 23 & 19.2 \\
\hline Years of experience & $1-10$ & 50 & 41.7 \\
& $11-20$ & 51 & 42.5 \\
& $21-30$ & 19 & 15.8 \\
\hline Household size (no of persons) & $3-10$ & 60 & 50.0 \\
& $11-17$ & 51 & 42.5 \\
\hline Extension contacts (no of times) & 18 and ABOVE & 9 & 7.5 \\
\hline Membership of cooperative & $1-2$ & 26 & 21.7 \\
& $3-4$ & 12 & 10.0 \\
\hline Annual income (naira) & No extension contact & 82 & 68.3 \\
\hline Yes & 54 & 45.0 \\
& No & 66 & 55.0 \\
\hline Farm size (hectares) & $51,000-150,000$ & 48 & 40.0 \\
& $151,000-250,000$ & 42 & 35.0 \\
& $251,000-350,000$ & 26 & 21.7 \\
\hline & $351,000-450,000$ & 4 & 3.3 \\
\hline & $0.2-0.6$ & 28 & 23.3 \\
& $0.7-1.1$ & 65 & 54.2 \\
& $1.2-1.6$ & 23 & 3.3 \\
\hline & 1.7 and ABOVE & 4 &
\end{tabular}

Source: Field Survey, 2016 


\subsection{Risk attitude of the farmers}

Following the procedure outlined in the methodology; the farmers risk aversion coefficient were estimated and presented in Table 3 and were subsequently grouped into risk averters and risk takers and as such presented in Table 4.

Table 3: Absolute risk aversion coefficient of the farmers

\begin{tabular}{|c|c|c|c|c|c|c|c|}
\hline $\begin{array}{l}\text { Farmer } \\
\text { number }\end{array}$ & $\begin{array}{l}\text { Absolute risk } \\
\text { aversion } \\
\text { coefficient }\end{array}$ & $\begin{array}{l}\text { Farmer } \\
\text { number }\end{array}$ & $\begin{array}{l}\text { Absolute risk } \\
\text { aversion } \\
\text { coefficient }\end{array}$ & $\begin{array}{l}\text { Farmer } \\
\text { number }\end{array}$ & $\begin{array}{l}\text { Absolute risk } \\
\text { aversion } \\
\text { coefficient }\end{array}$ & $\begin{array}{l}\text { Farmer } \\
\text { number }\end{array}$ & $\begin{array}{l}\text { Absolute risk } \\
\text { aversion } \\
\text { coefficient }\end{array}$ \\
\hline 1 & 0.000004954 & 31 & 0.000009770 & 61 & 0.00001091 & 91 & 0.000003688 \\
\hline 2 & 0.000006130 & 32 & 0.000009770 & 62 & 0.00001055 & 92 & -0.000001245 \\
\hline 3 & 0.000002640 & 33 & -0.000009590 & 63 & 0.00001112 & 93 & 0.0000009171 \\
\hline 4 & -0.00003615 & 34 & -0.000009590 & 64 & 0.000009770 & 94 & 0.00001014 \\
\hline 5 & -0.00005389 & 35 & -0.00002409 & 65 & -.000009590 & 95 & -0.000001124 \\
\hline 6 & 0.00001558 & 36 & 0.0000009171 & 66 & 0.000001608 & 96 & 0.00001608 \\
\hline 7 & 0.00001561 & 37 & 0.000004746 & 67 & -0.000001245 & 97 & 0.0000009171 \\
\hline 8 & 0.00001166 & 38 & 0.0000009171 & 68 & 0.00005554 & 98 & 0.00001608 \\
\hline 9 & 0.00000117 & 39 & -0.000009590 & 69 & 0.000009770 & 99 & -0.000009590 \\
\hline 10 & 0.000006327 & 40 & 0.0000009171 & 70 & -0.000009590 & 100 & 0.00005240 \\
\hline 11 & 0.000003184 & 41 & -0.000009590 & 71 & 0.00001608 & 101 & 0.00001608 \\
\hline 12 & 0.000003184 & 42 & -0.000009590 & 72 & 0.000009769 & 102 & 0.00001073 \\
\hline 13 & 0.00005956 & 43 & 0.0001198 & 73 & 0.00001608 & 103 & 0.000009769 \\
\hline 14 & 0.00001668 & 44 & -0.000009590 & 74 & -0.000009590 & 104 & 0.00001608 \\
\hline 15 & 0.00001668 & 45 & 0.000004813 & 75 & 0.00005554 & 105 & 0.000009769 \\
\hline 16 & 0.000002770 & 46 & 0.0000007041 & 76 & 0.000009715 & 106 & 0.000009769 \\
\hline 17 & 0.000003379 & 47 & 0.000004813 & 77 & 0.0000336 & 107 & -0.000009590 \\
\hline 18 & 0.000002770 & 48 & 0.0000009171 & 78 & -0.000009590 & 108 & -0.000009525 \\
\hline 19 & 0.000003184 & 49 & -0.000009590 & 79 & 0.00001604 & 109 & 0.0000009171 \\
\hline 20 & 0.00004254 & 50 & 0.000009770 & 80 & 0.00005554 & 110 & -0.000009575 \\
\hline 21 & 0.00001069 & 51 & 0.000002234 & 81 & 0.000009769 & 111 & -0.000009590 \\
\hline 22 & 0.000007467 & 52 & 0.00001041 & 82 & 0.000009769 & 112 & 0.000009229 \\
\hline 23 & 0.000003891 & 53 & 0.000005042 & 83 & 0.000009769 & 113 & 0.000009769 \\
\hline 24 & 0.0001 & 54 & 0.0000009171 & 84 & 0.000009769 & 114 & -0.000009590 \\
\hline 25 & 0.0001485 & 55 & 0.00001075 & 85 & -0.000009590 & 115 & 0.0000009171 \\
\hline 26 & 0.0001485 & 56 & 0.0000009171 & 86 & 0.000009769 & 116 & -0.000009590 \\
\hline 27 & 0.0001 & 57 & 0.000008466 & 87 & 0.00001704 & 117 & 0.000009769 \\
\hline 28 & 0.00001113 & 58 & -0.00002514 & 88 & 0.000009769 & 118 & 0.000009769 \\
\hline 29 & 0.00005680 & 59 & -0.000009590 & 89 & 0.00001608 & 119 & -0.000009575 \\
\hline 30 & -0.000001245 & 60 & -0.000009590 & 90 & 0.00001608 & 120 & 0.000009731 \\
\hline
\end{tabular}

Source: Authors Computation, 2016

Table 4: Distribution of the risk attitude of the farmers

\begin{tabular}{lll}
\hline Risk attitude & Frequency & Percentage \\
\hline Risk averse & 90 & 75.0 \\
Risk neutral & 0 & 0.00 \\
Risk loving & 30 & 25.0 \\
\hline Total & 120 & 100.0 \\
\hline
\end{tabular}

Source: Field Survey, 2016 
Tables 4 revealed that $75.0 \%$ of the farmers in the study area have positive Arrow-Pratt absolute risk aversion coefficients and were therefore categorized as risk averters. The remaining $25.0 \%$ of them have negative Arrow-Pratt absolute risk aversion coefficients and were grouped as risk seekers. However, none of the farmers has zero risk coefficients; an indication of risk indifference, hence none of the farmers was risk indifferent or neutral. The result of the study is a confirmation of the general assumption in the world of agriculture that farmers are risk averse and it is in line with empirical results of various studies (Sekar and Ramasamy, 2001; Korir, 2011).

\subsection{Sources of risk}

The unpredictability nature of the outcome of production with certainty is believed to emanate from several sources and as such this study help looked into the various sources of risk and it is presented in Table 5.

Table 5: Risk sources associated to the farmers in the study area

\begin{tabular}{|c|c|c|c|c|c|c|c|c|c|}
\hline Source of risk & VI & I & NS & NI & NVI & WS & MS & $\begin{array}{l}\text { MP } \\
\text { S }\end{array}$ & $\begin{array}{l}\text { RAN } \\
\text { K }\end{array}$ \\
\hline Pests & $\begin{array}{l}74 \\
(61.7)\end{array}$ & $\begin{array}{l}46 \\
(38.3)\end{array}$ & $\begin{array}{l}0 \\
(0.00)\end{array}$ & $\begin{array}{l}0 \\
(0.00)\end{array}$ & $\begin{array}{l}0 \\
(0.00)\end{array}$ & 554 & 4.62 & $\begin{array}{l}92.3 \\
4\end{array}$ & $1^{\text {st }}$ \\
\hline Diseases & $\begin{array}{l}73 \\
(60.8)\end{array}$ & $\begin{array}{l}45 \\
(37.5)\end{array}$ & $\begin{array}{l}2 \\
(1.7)\end{array}$ & $\begin{array}{l}0 \\
(0.00)\end{array}$ & $\begin{array}{l}0 \\
(0.00)\end{array}$ & 551 & 4.59 & $\begin{array}{l}91.8 \\
2\end{array}$ & $2^{\text {nd }}$ \\
\hline Price fluctuation & $\begin{array}{l}44 \\
(36.7)\end{array}$ & $\begin{array}{l}72 \\
(60.0)\end{array}$ & $\begin{array}{l}3 \\
(2.5)\end{array}$ & $\begin{array}{l}1 \\
(0.8)\end{array}$ & $\begin{array}{l}0 \\
(0.00)\end{array}$ & 519 & 4.33 & $\begin{array}{l}86.5 \\
2\end{array}$ & $3^{\text {rd }}$ \\
\hline Flood & $\begin{array}{l}36 \\
(30.0)\end{array}$ & $\begin{array}{l}83 \\
(69.2)\end{array}$ & $\begin{array}{l}1 \\
(0.8)\end{array}$ & $\begin{array}{l}0 \\
(0.00)\end{array}$ & $\begin{array}{l}0 \\
(0.00)\end{array}$ & 515 & 4.29 & $\begin{array}{l}85.8 \\
4\end{array}$ & $4^{\text {th }}$ \\
\hline Drought & $\begin{array}{l}48 \\
(40.0)\end{array}$ & $\begin{array}{l}60 \\
(50.0)\end{array}$ & $\begin{array}{l}11 \\
(9.2)\end{array}$ & $\begin{array}{l}1 \\
(0.8)\end{array}$ & $\begin{array}{l}0 \\
(0.00)\end{array}$ & 515 & 4.29 & $\begin{array}{l}85.8 \\
4\end{array}$ & $4^{\text {th }}$ \\
\hline Change in climate condition & $\begin{array}{l}34 \\
(28.3)\end{array}$ & $\begin{array}{l}84 \\
(70.0)\end{array}$ & $\begin{array}{l}2 \\
(1.7)\end{array}$ & $\begin{array}{l}0 \\
(0.00)\end{array}$ & $\begin{array}{l}0 \\
(0.00)\end{array}$ & 512 & 4.27 & $\begin{array}{l}85.3 \\
2\end{array}$ & $6^{\text {th }}$ \\
\hline Fertilizer & $\begin{array}{l}37 \\
(30.8)\end{array}$ & $\begin{array}{l}77 \\
(64.2)\end{array}$ & $\begin{array}{l}6 \\
(5.0)\end{array}$ & $\begin{array}{l}0 \\
(0.00)\end{array}$ & $\begin{array}{l}0 \\
(0.00)\end{array}$ & 511 & 4.26 & $\begin{array}{l}85.1 \\
6\end{array}$ & $7^{\text {th }}$ \\
\hline Erratic rainfall & $\begin{array}{l}23 \\
(19.2)\end{array}$ & $\begin{array}{l}83 \\
(69.2)\end{array}$ & $\begin{array}{l}11 \\
(9.2)\end{array}$ & $\begin{array}{l}3 \\
(2.5)\end{array}$ & $\begin{array}{l}0 \\
(0.00)\end{array}$ & 486 & 4.05 & $\begin{array}{l}81.0 \\
8\end{array}$ & $8^{\text {th }}$ \\
\hline Illness of household member & $\begin{array}{l}65 \\
(54.2)\end{array}$ & $\begin{array}{l}17 \\
(14.2)\end{array}$ & $\begin{array}{l}12 \\
(10.0)\end{array}$ & $\begin{array}{l}22 \\
(18.3)\end{array}$ & $\begin{array}{l}4 \\
(3.3)\end{array}$ & 477 & 3.98 & $\begin{array}{l}79.5 \\
4\end{array}$ & $9^{\text {th }}$ \\
\hline Excessive rainfall & $\begin{array}{l}18 \\
(15.0)\end{array}$ & $\begin{array}{l}80 \\
(66.7)\end{array}$ & $\begin{array}{l}19 \\
(15.8)\end{array}$ & $\begin{array}{l}3 \\
(2.5)\end{array}$ & $\begin{array}{l}0 \\
(0.00)\end{array}$ & 473 & 3.94 & $\begin{array}{l}78.8 \\
4\end{array}$ & $10^{\text {th }}$ \\
\hline Market failure & $\begin{array}{l}25 \\
(20.8)\end{array}$ & $\begin{array}{l}54 \\
(45.0)\end{array}$ & $\begin{array}{l}37 \\
(30.8)\end{array}$ & $\begin{array}{l}4 \\
(3.3)\end{array}$ & $\begin{array}{l}0 \\
(0.00)\end{array}$ & 460 & 3.83 & $\begin{array}{l}76.6 \\
0\end{array}$ & $11^{\text {th }}$ \\
\hline Insufficient family labour & $\begin{array}{l}22 \\
(18.3)\end{array}$ & $\begin{array}{l}25 \\
(20.8)\end{array}$ & $\begin{array}{l}16 \\
(13.3)\end{array}$ & $\begin{array}{l}40 \\
(33.3)\end{array}$ & $\begin{array}{l}17 \\
(14.2)\end{array}$ & 409 & 3.41 & $\begin{array}{l}68.0 \\
8\end{array}$ & $12^{\text {th }}$ \\
\hline $\begin{array}{l}\text { Change in govt. \& agricultural } \\
\text { policy }\end{array}$ & $\begin{array}{l}27 \\
(22.5)\end{array}$ & $\begin{array}{l}19 \\
(15.8)\end{array}$ & $\begin{array}{l}3 \\
(2.5)\end{array}$ & $\begin{array}{l}48 \\
(40.0)\end{array}$ & $\begin{array}{l}23 \\
(19.2)\end{array}$ & 339 & 2.83 & $\begin{array}{l}56.4 \\
8\end{array}$ & $13^{\text {th }}$ \\
\hline Difficulties of finding labour & $\begin{array}{l}6 \\
(5.0)\end{array}$ & $\begin{array}{l}26 \\
(21.7)\end{array}$ & $\begin{array}{l}20 \\
(16.7)\end{array}$ & $\begin{array}{l}51 \\
(42.5)\end{array}$ & $\begin{array}{l}17 \\
(14.2)\end{array}$ & 313 & 2.61 & $\begin{array}{l}52.2 \\
2\end{array}$ & $14^{\text {th }}$ \\
\hline Fire outbreak & $\begin{array}{l}13 \\
(10.8)\end{array}$ & $\begin{array}{l}13 \\
10.8\end{array}$ & $\begin{array}{l}21 \\
(17.5)\end{array}$ & $\begin{array}{l}44 \\
(36.5)\end{array}$ & $\begin{array}{l}29 \\
(24.2)\end{array}$ & 297 & 2.48 & $\begin{array}{l}49.3 \\
8\end{array}$ & $15^{\text {th }}$ \\
\hline Theft & $\begin{array}{l}10 \\
(8.3)\end{array}$ & $\begin{array}{l}18 \\
(15.0)\end{array}$ & $\begin{array}{l}14 \\
(11.7)\end{array}$ & $\begin{array}{l}18 \\
(15.0)\end{array}$ & $\begin{array}{l}60 \\
(50.0)\end{array}$ & 260 & 2.17 & $\begin{array}{l}43.3 \\
2\end{array}$ & $16^{\text {th }}$ \\
\hline
\end{tabular}

VI = Very important; I = Important; NS = Not sure; NI = Not important; NVI = Not very important; WS = Weighted score; MS = Mean score; MPS = Mean percent score. Figures in parenthesis are in percentages;Source: Field Survey, 2016 
Pests and diseases were recorded as the most important source of risk to the farmers as they were ranked first and second respectively. This corroborates with the findings of Obalola et al. (2017).

However, an insight into the price movement during the irrigation season indicates that the prices of onion fluctuate widely and as such is an important source of risk. It is generally the highest at the beginning of the season but falls rapidly until it reaches its lowest values at the peak of harvest period and the farmers are forced to sell their produce at low prices after which the prices begins to rise again.

Table 5 also reveals that drought, flood and change in climatic condition are important sources of risk to the farmers as it was ranked $4^{\text {th }}$ and $6^{\text {th }}$ respectively. This is in line with the findings of Ayinde et al. (2008) who reflected production risk in terms of weather to variation in yield of the crops over years and crop failures due to bad weather (drought or too much rain). Difficulty in finding labour was not seen as a bottleneck in their production and as such could pose little or no threat to the farmers. This was proven by a $42.5 \%$ response who considers difficulties in finding labour not important and it was ranked $14^{\text {th }}$. It was observed that the respondents do not consider theft as a factor as it was recorded that $50.0 \%$ of them indicated it as not very important.

\subsection{Coping strategies}

The strategies that can help in coping or minimizing the source of risk faced by the farmers in the study area are captured and presented in Table 6.

Table 6: Risk management strategies

\begin{tabular}{|c|c|c|c|c|c|c|c|c|c|}
\hline Risk management strategies & VI & $\mathrm{I}$ & NS & NI & NVI & WS & MS & MPS & RANK \\
\hline Investing off-farm & $\begin{array}{l}84 \\
(70.0)\end{array}$ & $\begin{array}{l}34 \\
(28.3)\end{array}$ & $\begin{array}{l}2 \\
(1.7)\end{array}$ & $\begin{array}{l}0 \\
(0.00)\end{array}$ & $\begin{array}{l}0 \\
(0.00)\end{array}$ & 562 & 4.68 & 93.66 & $1^{\mathrm{st}}$ \\
\hline Spraying for diseases \& pests & $\begin{array}{l}75 \\
(62.5)\end{array}$ & $\begin{array}{l}44 \\
(36.7)\end{array}$ & $\begin{array}{l}1 \\
(0.8)\end{array}$ & $\begin{array}{l}0 \\
(0.00)\end{array}$ & $\begin{array}{l}0 \\
(0.00)\end{array}$ & 554 & 4.62 & 92.34 & $2^{\text {nd }}$ \\
\hline Adashe (Cash contribution) & $\begin{array}{l}69 \\
(57.5)\end{array}$ & $\begin{array}{l}51 \\
(42.5)\end{array}$ & $\begin{array}{l}0 \\
(0.00)\end{array}$ & $\begin{array}{l}0 \\
(0.00)\end{array}$ & $\begin{array}{l}0 \\
(0.00)\end{array}$ & 549 & 4.58 & 91.50 & $3^{\text {rd }}$ \\
\hline Gathering market information & $\begin{array}{l}49 \\
(40.8)\end{array}$ & $\begin{array}{l}68 \\
(56.7)\end{array}$ & $\begin{array}{l}3 \\
(2.5)\end{array}$ & $\begin{array}{l}0 \\
(0.00)\end{array}$ & $\begin{array}{l}0 \\
(0.00)\end{array}$ & 526 & 4.38 & 87.66 & $4^{\text {th }}$ \\
\hline Training \& education & $\begin{array}{l}48 \\
(40.0)\end{array}$ & $\begin{array}{l}70 \\
(58.3)\end{array}$ & $\begin{array}{l}2 \\
(1.7)\end{array}$ & $\begin{array}{l}0 \\
(0.00)\end{array}$ & $\begin{array}{l}0 \\
(0.00)\end{array}$ & 526 & 4.38 & 87.66 & $4^{\text {th }}$ \\
\hline Borrowing & $\begin{array}{l}44 \\
(36.7)\end{array}$ & $\begin{array}{l}45 \\
(37.5)\end{array}$ & $\begin{array}{l}20 \\
(16.7)\end{array}$ & $\begin{array}{l}9 \\
(7.5)\end{array}$ & $\begin{array}{l}2 \\
(1.7)\end{array}$ & 480 & 4.00 & 80.06 & $6^{\text {th }}$ \\
\hline Cooperative societies & $\begin{array}{l}39 \\
(32.5)\end{array}$ & $\begin{array}{l}31 \\
(25.8)\end{array}$ & $\begin{array}{l}32 \\
(26.7)\end{array}$ & $\begin{array}{l}18 \\
(15.0)\end{array}$ & $\begin{array}{l}0 \\
(0.00)\end{array}$ & 451 & 3.76 & 75.16 & $7^{\text {th }}$ \\
\hline Selling of assets & $\begin{array}{l}12 \\
(10.0)\end{array}$ & $\begin{array}{l}12 \\
(10.0)\end{array}$ & $\begin{array}{l}31 \\
(25.8)\end{array}$ & $\begin{array}{l}55 \\
(45.8)\end{array}$ & $\begin{array}{l}10 \\
(8.3)\end{array}$ & 331 & 2.76 & 53.46 & $8^{\text {th }}$ \\
\hline
\end{tabular}

VI = Very important; I = Important; NS = Not sure; NI = Not important; NVI = Not very important; WS = Weighted score; MS = Mean score; MPS $=$ Mean percent score. Figures in parenthesis are in percentages

Source: Field Survey, 2016

Investing off-farm was ranked as first as a very important strategy in managing risk. Ayinde et al. (2008) have shown the importance of diversification (investment in more than one portfolio) as important risk management strategies for agricultural enterprises.

Spraying for diseases and pests was ranked second. This is not surprising considering the fact that pest and diseases were identified as a very important source of risk. Therefore, spraying for pests as well as diseases could help manage the riskiness attributed to it and as such help improve farmer's production and at the same time their productivity. This is in conformity with the finding of Obalola et al. (2017) who revealed that incidence of pests and diseases are the major problem limiting farmers output. 
In addition, cash contribution was ranked third as management strategy to help manage risk in the study area. Training and education was recorded as an important factor that helps to minimize risk. This was proven by $58.3 \%$ of the farmers highlighting it as important and as such ranked $4^{\text {th }}$. If the farmers are educated and trained, it could go a long way in helping improve the awareness level of the farmers with regards to a better perception of themselves and their problems.
It is important to note that most of the farmers use more than one coping strategy in the face of risks.

Other risk management strategies recorded in increasing order of importance are borrowing (37.5\%) and cooperative societies $(32.5 \%)$. It was however revealed that selling of assets is not an important factor in risk management as $45.8 \%$ of the farmers attest to it and thus, ranked $9^{\text {th }}$.

\section{CONCLUSION}

The majority of onion farmers were found to be risk averse. However, it should be noted that most of the sources of risk highlighted by the farmers could be analyzed within the context of the farmers operational level and can be managed by the farmers, if motivated in one way or another either by training and education, diversification of the enterprise (off-farm investment), crop insurance, spraying for pests and diseases etc.

The study therefore recommends programmes towards education and diversification. The farmers were found to be risk averse implying that they were not fully insured by their self-insurance strategies. In order to improve this, policies that enhance access to insuring farm activities should be put in place.

This can however be achieved by improving and intensifying extension services to impact technical and economic knowledge on farmers especially the farmers with few years of experience.

\section{REFERENCES}

Ayinde, O.A., Omotesho, A.O., \& Adewunmi, M.O. (2008). Risk attitudes and management strategies of small-scale crop producers in Kwara State, Nigeria: A ranking approach. African Journal of Business Management, 2(12), 217-221.

Binici, T., Koc, A.A., Zulauf, C.R., \& Bayaner, A. (2003). Risk attitudes of farmers in terms of risk aversion: A case study of lower seyhan plain farmers in adana province, Turkey. Turkish Journal of Agriculture, 27, 305-312.

Kay, R.D. (1981). Farm management, planning, control and implementation: 334-353. McGraw Hill Book Company.

Korir, L.K. (2011). Risk Management among Agricultural Households and the Role of Off-Farm Investments in Uasin Gishu County, Kenya. Thesis submitted to the Graduate School in Partial fulfillment for the Requirements of Master of science Degree in Agricultural and Applied Economics of Egerton University: 1-74

Obalola, T. O., Agboola, B. O., \& Odum, E. B. E. (2017). Profitability and Constraints to Irrigated Onion Production in Wamakko and Kware Local Government Areas, Sokoto State, Nigeria. Journal of Global Agriculture and Ecology, 7(3), 106-110.

Ojo, M.A., Muhammed, U.S., Adeniji, B., \& Ojo, A.O. (2009). Profitability and Technical Efficiency in irrigated onion production under middle rima valley irrigation project in Goronyo, Sokoto State. Nigeria. Journal of Agricultural Science, 3, 7-14.

Okoruwa, V.O., Akindeinde, A.O., \& Salimonu, K.K. (2009). Relative economic efficiency of farms in rice production: A profit function Approach in North Central Nigeria Tropical and Sub-tropical. Agroecosystem, 10, 279-286.

Olarinde, L.O., Manyong, V.M., \& Okoruwa, V.O. (2008). Analysing optimum and alternative farm plans for risk averse grain crop farmers in Kaduna State, Northern Nigeria. World Journal of Agricultural Sciences, 4(1), 28-35.

Sekar, I., \& Ramasamy, C. (2001). Risk and resource analysis of rainfed tanks in South India. Journal of Social and Economic Development, 3(2), 208-215.

Singh, B. R. (1995). Soil management strategies for the semiarid ecosystem in Nigeria: The case of Sokoto and Kebbi States. African Soils, 28, 317-320.

Singh, B. R. (2000). Quality of irrigation water in fadama lands of north-western Nigeria II. Tube-well waters in Zamfara State. Nigeria Journal of Basic and Applied Sciences, 9, 191-193.

Tsoho, B.A., \& Salau, S.A. (2012). Profitability and Constraints to dry season Vegetable production under fadama in sudan savannah ecological zone of Sokoto State, Nigeria. Journal of Development and Agricultural Economics, 4(7), 214-222. 